\title{
Role of phytolectin in the life cycle of plants
}

\author{
N. V. Kovalchuk ${ }^{1,3}$, N. M. Melnykova ${ }^{2}$, L. I. Musatenko ${ }^{3}$ \\ ${ }^{1}$ Australian Centre for Plant Functional Genomics, \\ The University of Adelaide \\ PMB 1, Glen Osmond, SA 5604, Australia \\ ${ }^{2}$ Institute of Plant Physiology and Genetics, NAS of Ukraine \\ 31/17, Vasylkivska Str., Kyiv, Ukraine, 03022 \\ ${ }^{3}$ M. G. Kholodny Institute of Botany, NAS of Ukraine \\ 2, Tereschenkivska Str., Kyiv, Ukraine, 01601 \\ mnn69@mail.ru
}

\begin{abstract}
In the review the basic properties of plant lectins and their physio-logical role in the life cycle of plants are considered. There are data on the current state of the researches of phytolectins and lectin-like pro-teins as well as designation of the main directions of further study on the functioning of these proteins in the plant physiological processes.
\end{abstract}

Keywords: phytolectins, carbohydrate binding properties, physio-logical role, life cycle.

Introduction. Plants synthesize a vast amount of protein molecules, which participate in different processes in the course of its life cycle. Lectins and lectin-like proteins, which form a separate group, were isolated from different organs and tissues of plants [1]. Lectins are predominantly glycoproteins of nonimmune origin, capable both of binding carbohydrates and compounds containing carbohydrates with high specificity and of agglutinating erythrocytes [2]. Normally [a] lectin molecule contains several similar or different subunits [2], although there are monomeric lectins [3]. One of the most important properties of hemagglutinating proteins is their capacity to interact with carbohydrate ligands, thus revealing considerable specificity $[1,2]$. The lectins of plants differ in carbohydrate specificity [2] and are able to interact with several mono- and oligosaccharides with different degree of activity [4]. Agglutinating proteins may have the highest affinity to complex oligosaccharides and compounds containing carbohydrates if compared to monosaccharides and simple oligosaccharides [3].

(C) Institute of Molecular Biology and Genetics, NAS of Ukraine, 2012
Some amino acid residues in the active center of carbohydrate-binding site of the lectin play a significant role in binding to monosaccharides [5], while others are involved in the interaction of the protein molecule with complex carbohydrate compounds, thus enhancing its affinity $[6,7]$. Besides the carbohydrate site, the agglutinins may contain sites, by which they interact with adenine and phytohormones - adenine derivatives [8], as well as with other molecules, some amino acids, in particular [9]. Phytolectins are capable of agglutinating erythrocytes of humans and different animals, but some of them predominantly bind erythrocytes of a specific kind [2]. It was demonstrated that some lectins also show a catalytic activity, for instance, agglutinin of Dolichos biflorus seeds has lipoxygenase activity [10].

In addition to so called classic lectins, plants also synthesize lectin-like proteins, arcelin and $\alpha$-amylase inhibitor [11], in particular, which are capable of interacting with carbohydrates and have some homology to the known lectins. The authors of [12] considering all plant proteins with at least one non-catalytic domain, suggested that reversibly binding specific mono- or 
oligosaccharides are plant lectins. Special attention should be attributed to lectin receptor kinases and $\beta$-galactosidase, which also contain a lectin domain $[13,14]$. In some plants, for instance, alfalfa, was identified lectin gene MsLEC1 [15]. However, there are no current data on the properties of this protein.

The results of a number of researches allow the assumption on non-classic lectins representing the main evolution line, while their corresponding genes serve as a sample for genes, encoding "classic" lectin homologues [16].

The lectins structure and localization in plant cells, tissues and organs, as well as their physical and chemical and immunochemical properties are responsible for the functional activity of these proteins in the course of life cycles of plants at different levels of organization starting from a cell to the whole organism.

The functional activity of hemagglutinins in plants was studied for a long time, and the results were described in many scientific works $[1,2,6,16]$. The generalization of modern data on the role of lectins and lectin-like proteins in different processes of the life cycle of plants will allow defining the areas of research, which have not attracted sufficient attention yet but could be of great significance for deepening and expanding the knowledge about lectins, the participation of these proteins in recognition as a general biological phenomenon, etc. The data on the phytolectins features and physiological role may become the basis for practical application of agglutinating proteins.

Role of lectins as a storage substance. Considerable accumulation of hemagglutinins in storage tissues of plants and their degradation during seed germination [17] or as a result of fluctuating changes in the bark of leguminous trees [18] allowed an assumption on the role of phytolectins as a storage substance providing, along with other proteins, the development of a plant organism. However, it was shown that during seed germination the content of lectin decreases much less than other proteins. It may testify to some other role of lectins on early stages of plant growth and development [19]. Probably, the phytolectin storage role is not the essential role of phytolectins which is confirmed by the absence of direct evidence of their functioning as storage proteins. Chances are that they (for instance, hemagglutinins of seeds or bark) are able to function in the aggregation of proteins and enzymes $[20,21]$. The decrease in the amount of lectin during the seed germination may be on the one hand due to its secretion outwards (among other things, arole in the plant protection ), and on the other - to the degradation, caused by the loss of significance of agglutinin as an aggregating component, since the pool of storage proteins disappear with the seedling growth.

Participation of phytolectins in the growth and development of plants. It was shown that a considerable number of lectins are synthesized in the zones of the most active growth of seedlings which is an indirect indication of their role in the growth processes of the plant organism [22]. This assumption is confirmed by the data on the increase in the level of mRNA of the vegetative lectin CanVLEC while treating Cicer arietinum plants with the indole acetic acid and brassinolides, causing the extension of epicotyl, while the number of lectin transcripts decreases in course of epicotyls growth [23]. Exogenous lectins are capable of stimulating growth processes in the roots of seedlings and mitotic activity of cells of their apical meristem, thus revealing some specificity of their action [24]. The growth activity of plants is known to considerably depend on the impact of phytohormones [25]. The results of a number of researches indicate a close connection between the content of phytohormones and plant lectins. For instance, the treatment of the seedlings roots of Phaseolus vulgaris with phytohemagglutinin (PHA) caused quantitative changes in hormones of the roots which may indicate the involvement of this lectin in the hormonal regulation of plant growth [24]. On the other hand, phytohormones are capable of enhancing the expression of lectin genes and increasing the amount of hemagglutinins in plants [26, 27]. However, no lectins were synthesized in the course of cultivating the callus cells of D. biflorus on the medium with the addition of 2,4-dichlorphenoxyacetic acid and kinetin. The production of hemagglutinating proteins occurred after the transfer of a culture to the hormone-free medium [28]. The changes in the activity of cell division of wheat roots under simultaneous action of wheat germ agglutinin and 24-epibrassinolide indicate the possible interaction of phytohormones and lectins in the control of growth processes in plants [29]. Taking into consideration the ability of lectins to bind 
phytohormones with high affinity [8], it is logical to assume the role for hemagglutinating proteins to accumulate some amounts of hormones participating in the regulation of plant growth and development. The study on the structure of lectin from Viscum album in the complex with zeatin confirms this thought demonstrating the ability of hemagglutinating proteins to bind phytohormones [30]. Here the adsorption of the hormones of host plants by the lectin of $V$. album is supposed to be a part of the protective mechanism of mistletoe [30]. The lectins may also function as a component of the protective hormone[-]dependent signaling mechanism $[31,32]$.

One of the possible ways of the interaction between lectins and phytohormones in the ontogeny of plants may be the binding of hemagglutinating proteins to cellular walls and the inhibition of the auxin-induced cell wall loosening. Thus, the lectins of Tetragonolobus purpureus and Ulex europeaus inhibit the elongation of segments of the epicotyl of Vigna angularis [33], while the concanavallin A, the germ agglutinin of Triticum vulgaris, the lectins of $D$. biflorus, Glycine max, and Limulus polyphenus suppress the elongation of the coleoptile of oats (Avena sativa L.), induced by auxin [34]. The experimental data evidence that lectin receptor kinases, containing the site of binding phytohormones [35], may participate in either positive or negative regulation of seed germination in response to the abscisic acid action [36, 37].

Regulatory role of agglutinins. In addition to the involvement in hormonal regulation of plant growth [24], the lectins may be involved in the sustaining and functioning of enzyme complexes which provide the number of important physiological processes in the life cycle of a plant organism. For instance, after the alkalization of the stroma thylakoids in the light, the carbohydrate-binding site of the pigment-protein complex of the photosystem I is transformed into the active state, enhancing the activity of ribuloso-1,5-bisphosphatecarboxylase, which is a specific ligand of the lectin in stroma thylakoids [38]. Jacalin-like lectins demonstrated their capability to regulate the size of the glucosidase complex located in specialized organelles of the endoplasmic reticulum of Arabidopsis thaliana cells. One of them plays an inhibitory role, while the other protein is capable of polymerization [39].
The transport role of lectins. The similarity in general structures of carbohydrate-binding sites of the lectins of some leguminous plants and the proteins which transfer sugars [40] testifies to the possible participation of agglutinins in the transportation of carbohydrates. The phloem protein of cucumber PP2, which is a chimeric lectin, demonstrated its ability to interact with RNA of viroids and move via plasmodesmas from cell to cell at considerable distances [41]. The sequence, typical for protein molecules, which are capable of binding to highly structured RNA, was identified in the gene of PP2 protein [42]. Based on these and some other researches, an assumption was made regarding probable transfer of endogenous plant RNA by phloem lectins of cucumber and melon [42, 43]. It was revealed that the recombinant lectin PP2-A1 of $A$. thaliana may interact with $\mathrm{N}$-acetyl glucosamine oligomers and high-mannose $\mathrm{N}$-glycans as well as with some proteins of phloem juice, which indicates the functional activity of the lectin in course of transfer of endogenous proteins [44].

Participation of phytolectins in fruit development and ripening. The lectins of plants may stimulate the growth of the pollen tube [45] and are significant for the recognition during the pollination of plants [46]. It was shown that during the maturation of seeds of $P$. vulgaris the hemagglutinating activity of PHA in cotyledons was slightly decreased starting from the 40th day after the pollination of plants, while embryonic axes showed the increase in hemagglutinating activity [47]. In particular, this testifies to the functional activity of PHA when the seeds go into dormancy. The changes in activity and carbohydrate specificity of hemagglutinins of subcellular fractions of cauline apexes of Rudbeckia bicolor and Perilla nantkinansis during the photoperiodic induction [48] allow the suggesting about participation of lectins in the processes related to the beginning of flowering stage.

The hemagglutinating proteins of plants may also be important during fruit ripening. For instance, in the presence of the tomato lectin and concanavallin A the glycan Man5GlcNAc, which inhibits the tomato pericarp disk reddening induced by the indole acetic acid [49], loses its biological activity [50].

Role of lectins in plant protection. Phytolectins may participate in the plant protection from a negative 
impact of quite a number of environmental factors. For instance, the temperature stress significantly intensifies the PHA synthesis in cotyledons of $P$. vulgaris [51]. It was established that the lectin has a close evolutionary relationship with the domain identified in some proteins that are synthesized in response to salt stress and abscisic acid [52]. This lectin is likely to play a role inherent in stress proteins. A number of investigations, determining the hemagglutinating activity of lectin-like components in cellular walls and external membranes of organelles (such as a nucleus, plastids, mitochondria and microsome membranes) of winter wheat plants of Triticum aestivum resistant to winterkilling, allowed the assumption that just the components of organelle external membranes control their functional activity in adapting to cold [53]. Obviously, during the adaptation of plants to low temperatures the lectins are involved into the interaction between the wall of a plant cell and the cytoskeleton [54].

Recent experimental data allow considering phytolectins as a possible component of the plant system of defense against consequences of the negative impact of water deficiency. For instance, a decrease in the amount of water, which enters the seedlings, influences the expression of CanVLEC gene encoding the vegetative lectin of $C$. arietinum [23]. It was established that exogenous treatment by wheat germ agglutinin may protect wheat seedlings from salinization due to decrease in the activity of antioxidant enzymes and prevent an increase in the mitotic activity of the root apical meristem caused by the salt stress [55]. It is necessary to note that the exact mechanisms and processes with lectin participation, which take place in the plant organism under the influence of abiotic factors, are yet to be elucidated.

Some hemagglutinins may be involved in the plant protection from an impact of different phytopathogens, inhibiting the growth of microscopic fungi, for instance $[56,57]$. Lectins with different carbohydrate specificity, binding with the germ tube of spores of Neurospora crassa, Aspergillus amstelodami, Botryodiplodia theobromae, are able to inhibit the spores growth by changing their sensitivity to the osmolytic lysis, or causing the branching, or inhibiting the elongation of germ tubes of spores [58]. However, the degree of manifestation of the agglutinin inhibitory activity may considerably depend on the growth phase of fungi [59]. The treatment of Nicotiana tabacum with the arachidonic acid and the inoculation with tobacco mosaic virus resulted in an increase in the hemagglutinating activity in plants, which may testify to the involvement of lectin into the development of antiviral defense response [60]. The proteins with lectin domain participate in the protection of plants from the affection by phytopathogens as a component of the signaling system. For instance, the lectin receptor kinase from Nicotiana benthamiana leaves demonstrated its ability to interact with INF elicitin of Phytophtora infestans and transmit the hypersensitivity signal, thus causing the death of plant cells [61].

Phytolectins may play a role in the protection of plants from insect pests. For instance, PHA from P. vulgaris seeds reveals the insecticidal activity against Schizaphis graminum [62], and arcelin - with respect to Zabrotes subfasciatus [63]. $\alpha$-Amylase inhibitor of $P$. vulgaris is capable of inhibiting $\alpha$-amylases of animal origin [64], and $\alpha$-amylase inhibitor from Lablab purpureus $-\alpha$-amylase of fungi, suppressing conidial germination and the growth of hyphae of Aspergillus flavus, a corn pathogenic fungus [65]. It was shown that the lectins of different plant species have considerable effect on the number of eggs laid by female Callosobruchus maculatus if used to treat the seeds of C. arietinum showing the specificity related to the carbohydrate-binding properties of agglutinating proteins [66]. The negative influence of phytolectins on animals may be due to, for instance, the ability of these proteins either to bind to cells (the lectin of Glechoma hederacea leaves) [67], or inhibit the protein synthesis in case of ricin (RIP protein, type 2) [68], or inhibit the enzymatic activity ( $\alpha$-amylase inhibitor) [64]. It should be noted that in the process of damaging some plants the insects may induce the synthesis of lectins with the specificity to high-mannose N-glycans [69], the effect of which is likely to be directed towards the protection of a plant organism.

Role of plant lectins in the formation of plant-microbe interrelations. Due to the secretion into the environment during germination [70] or from the root system of plants [71] phytolectins may play a significant role in the formation of interrelations between plants and soil microorganisms. The role of 
lectins during the development of symbiosis between the leguminous plant and nodule bacteria is supposed to be the recognition of symbiosis partners $[72,73]$ which is considerably dependent on carbohydrate-binding properties of agglutinating proteins [74, 75]. It was established that legume hemagglutinins with high specificity interact with the acid polymers of nodule bacteria surface and "anchor" bacteria on the surface of plant root [72], thus promoting the development of the rhizobium-legume symbiosis. These data formed the basis of the 'lectin' hypothesis of the recognition. Modern researches demonstrated that lectin/nucleotide phosphohydrolases synthesized in roots of some plants, D. biflorus and Glycine soja, in particular, are capable of interacting with Nod-factors of homologous rhisobia $[76,77]$, playing a significant role in the recognition of symbiosis partners. The modeling of the structure of lectin receptor kinases allowed the assumption that these proteins are likely to bind the molecules of lipochitin oligosaccharides [78]. The mutations in the genes of lectin receptor kinases lead to the changes in the activity of the nodule formation, which indicates the role of these proteins in the formation of symbiotic nitrogen-fixing systems. It was shown that the lectin-like glycoprotein PsLEC1 is synthesized in pea nodules [79] and participates in the processes accompanying the formation of a symbiosome [80], a compartment with bacteroids, where the nitrogen fixation occurs. The glycoprotein is capable of interacting with the peribacteroid membrane and the nodule bacteria surface [81]. The investigation of the expression of MsLecl, a lectin gene of Medicago sativa, demostrated its relevance for the symbiosis formation [15].

Numerous experiments on transgene leguminous plants, which were introduced with foreign lectin genes, confirmed the relevance of hemagglutinating proteins in the rhizobium-legume symbiosis formation. For instance, the inoculation of Lotus corniculatus, containing the soybean lectin gene, by nodule bacteria of Bradyrhizobium japonicum (strict symbiont of soybean) caused the formation of nodule-like structures on plant roots [82]. The introduction of the genes of pea lectin PSL or lectin/nucleotide phosphohydrolase GS52 of G. soja into the genome of non-leguminous plant of Orysa sativa demonstrated that the expression of PSL and GS52 enhances considerably the colonization of root epidermal cells and hairs under the inoculation of rice with Rhizobium leguminosarum bv. viciae or B. japonicum, causing the local cell wall loosening of root hair tips [83]. The experimental data were obtained that transgene roots of red clover express the pea lectin PSL and develop the structure, similar to nodule primordium, not only during the inoculation of plants with rhizobia but also in case of treating them with heterogeneous lipochitin oligosaccharides. This allowed the assumption on the capability of lectins to decrease the sensitivity threshold of the root cells to the influence of Nod-factors [75], which are the oligochitosaccharides synthesized by nodule bacteria and play a significant role in the formation of rhizobium-legume symbiosis [84].

The legume lectins secreted by plants into the rhizosphere may influence the competitive capacity of nodule bacteria, their growth activity and adhesive properties $[85,86]$. It was shown that the soybean lectin may provide the biofilm formation by nodule bacteria B. japonicum [87]. At the same time the treatment of nodule bacteria with plant agglutinating proteins has considerable impact on the processes related to the respiration of microorganisms [88] and the synthesis of exoglycans [85]. One of the ways of the influence of legume lectins on the formation of plant-microbe symbiotic interrelations may be the change in the activity of the nodule formation by rhizobia and the reduction of atmospheric nitrogen by the symbiotic system 'leguminous plant-nodule bacteria' [89, 90].

The difference between the lectins, isolated from various cultivars of the same species of the leguminous, in binding carbohydrates may somewhat influence the functional capability of hemagglutinins in the formation of rhizobium-legume symbiosis and the binding of nodule bacteria polysaccharides $[4,89]$.

Some agglutinating proteins, interacting with the cells of external part of root tip of leguminous plant (for instance, Macroptilium atropurpureum) and the channels between epidermal walls in its elongation zone, are capable of inhibiting the nodule formation by specific rhizobia [91]. It testifies to the possibility of allelopathic activity of lectins.

It is noteworthy that hemagglutinating proteins may participate in the symbiosis formation between plants 
and arbuscular mycorrhiza [92] and in the development of associative interrelations between plants and rhizospheric microorganisms. For instance, the presence of wheat germ agglutinin caused an increase in the nitrogen fixation of Azospirillum lipoferum and enhanced transcription of a number of genes responsible for the capability of microorganisms to fix atmospheric nitrogen [93]. An addition of wheat germ agglutinin to the culture of Azospirillum brasilense resulted in the increase of indolil acetic acid concentration and ammonium excretion as well as in the protein synthesis activation [94]. Also phytolectins demonstrate the antimutagenic effects on bacteria of Bacillus subtilis at the toxic influence of $\mathrm{Ni}$ (II) ions by activation of the cell reparation system [95].

Perspectives of studying a role of lectins in the life cycle of plants. Lectins are carbohydrate proteins wide-spread in different organisms from viruses to people. They play an important role in the processes of intercellular and intracellular recognition $[1,2,15,72]$. The proteins with lectin domains, due to their highly specific interaction with carbohydrate determinants, are capable of deciphering the glycocode [96], and as a result the cell metabolism is changed $[35,76]$. Hemagglutinins may serve as signaling molecules for the manifestation of microorganism physiological activity since their interaction with, for instance, microbe cells leads to some changes in the biosynthesis of relevant compounds] [94]. Phytolectins and proteins with lectin domain can bind not only the carbohydrates of different complexity but also adenine and aminoacid derivatives and different proteins, in particular, enzymes. This confirms the participation of hemagglutinins in regulatory processes $[31,35]$.

The application of novel genetic and molecular biology techniques in recent decades revealed new possibilities for studying a physiological role of phytolectins in the life cycle of plants, especially the mechanisms of carbohydrate-binding proteins action. The study on the genes of lectins may be an essential stage in the determination of a role of these proteins in a plant organism [97] since there are lectins, which are synthesized during some specific period [98] or present in plant tissues in inconsiderable amounts [99], therefore, their isolation and analysis are complicated. The experimental data demonstrate that the genome of plants may contain a number of sites presumably responsible for the production of lectins or lectin-like proteins [79]. The application of cDNA and microbe systems capable to of expression of lectin genes allows obtaining recombinant lectin molecules and studying their structure and properties [100].

The active investigations of lectin genes and structural peculiarities of plant hemagglutinins in recent years are important not only for understanding molecular basis of recognition but also for creating lectin molecules of certain specificity $[7,101]$. Considerable attention of scientists is paid to the study on lectin receptor kinases $[13,78]$ and transgenic plants carrying lectin genes that promotes the disclosure of mechanisms of hemagglutinins action [75] and the determination of ways for increasing the resistance of plants to the impact of phytopathogens [102]. Another urgent issue is the identification of new hemagglutinating proteins of plants [103].

Although the study on phytolectins has been conducted for a long time, their role during the specific stages of plant development is yet to be revealed. A number of directions in the research of phytolectins physiological activity need further consideration, because the results of many experimental works, aimed at the determination of amount of lectins or their activity [53], testify only to a probable role of these proteins in the life cycle of plants. It seems to be of high relevance to discover the mechanisms of the impact of plant agglutinins in case of abiotic stress. Intense study on the inducible plant lectins may be significantly valuable for the determination of their functional peculiarities and participation in the work of systems which provide the realization of adaptation potential of different plant species. The investigation of plant genome allowed finding numerous lectin genes; the relevance of proteins produced by these genes is yet unknown exactly. While studying the phytolectin functional activity it is essential to solve the question of their role as an exogenous factor, which may considerably influence the physiological status of plants in context of an allelopathic effect of carbohydrate-binding proteins.The mechanisms of phytolectins prolonged action are still incomprehensible [104].

The findings on the role of phytolectins along with the determination of their structure and properties may 
be used in practice, for instance, for the purpose of increasing the plant resistance to the stress factors. Thus, the investigation of phytolectins, in particular, their role in different processes during the life cycle of plants, is of great importance due to the prevalence of these proteins in plants and the significance of their interactions with carbohydrates at different levels and stages of the plant growth and development.

Н. В. Ковальчук ${ }^{1,3}$, Н. М. Мельникова ${ }^{2}$, Л. І. Мусатенко ${ }^{3}$

Роль фітолектинів у процесах життєдіяльності рослин

${ }^{1}$ Австралійський центр функціональної геноміки рослин, Університет Аделаїди

РМВ1, Глен Осмонд, СА 5604, Австралія

${ }^{2}$ Інститут фізіології рослин і генетики НАН України

Вул. Васильківська, 31/17, Київ, Україна, 03022

${ }^{3}$ Інститут ботаніки ім. М. Г. Холодного НАН України

Вул. Терещенківська, 2, Київ, Україна, 01601

Резюме

В огляді висвітлено основні властивості рослинних лектинів та узагальнено літературні дані щзодо фізіологічної ролі ичих білків у життєвому ичиклі рослин. Приділено увагу сучасним дослідженням фітолектинів і лектиноподібних білків, а також окреслено основні напрямки подальшого вивчення функ- иіонування гемаглютинінів у фізіологічних процесах рослин.

Ключові слова: фітолектини, вуглеводзв'язувальні властивості, фізіологічна роль, життєвий ичклл.

\section{Н. В. Ковальчук, Н. Н. Мельникова, Л. И. Мусатенко}

Роль фитолектинов в процессах жизнедеятельности растений

\section{Резюме}

В обзоре освещены основные свойства растительных лектинов и обобщены литературные данные по физиологической роли этих белков в жизненном циикле растений. Уделено внимание современным исследованиям фитолектинов и лектиноподобных белков, а также очерчены основные направления дальнейшего изучения функционирования гемагглютининов в физиологических процессах растений.

Ключевые слова: фитолектины, углеводсвязываюшче свойства, физиологическая роль, жизненный циикл.

\section{REFERENCES}

1. Antonyuk $V$. O. Lectins and their stock sources.-Lviv: Kvart, 2005.-554 p.

2. Lutsyk M. D., Panasyuk E. N., Lutsyk A. D. Lectins.-Lviv: Vyshcha Shkola, 1984.-155 p.

3. Hori K., Matsubara K., Miyazawa K. Primary structure of two hemagglutinins from the marine red alga, Hypnea japonica // Biochim. Biophys. Acta.-2000.-1474, N 2.-P. 226-236.
4. Kosenko L. V. Comparative characteristics of carbohydrate binding by lectins from broad bean, pea, common vetch, and lentil seeds // Russ. J. Plant Physiol.-2002.-49, N 5.-P. 641-646.

5. Sreevidya V. S., Hernandez-Oane R. J., So R. B., Sullia S. B., Stacey G., Ladha J. K., Reddy P. M. Expression of the legume symbiotic lectin genes $p s l$ and gs52 promotes rhizobial colonization of roots in rice // Plant Sci.-2005.-169, N 4.-P. 726-736.

6. Loris R., Hamelryck T., Bouckaert J., Wyns L. Legume lectin structure // Biochim. Biophys. Acta.-1998.-1383, N 1.-P. 9-36.

7. Pratap J. V., Jeyaprakash A. A., Rani P. G., Sekar K., Surolia A., Vijayan $M$. Crystal structures of artocarpin, a Moraceae lectin with mannose specificity, and its complex with methyl-alphaD-mannose: implications to the generation of carbohydrate specificity // J. Mol. Biol.-2002.-317, N 2.-P. 237-247.

8. Bogoeva V. P., Radeva M. A., Atanasova L. Y., Stoitsova S. R., Boteva R. N. Fluorescence analysis of hormone binding activities of wheat germ agglutinin // Biochim. Biophys. Acta.-2004.1698, N 2.-P. 213-218.

9. Delatorre P., Rocha B. A., Souza E. P., Oliveira T. M., Bezerra G. A., Moreno F. B., Freitas B. T., Santi-Gadelha T., Sampaio A. H., Azevedo W. F. Jr., Cavada B. S. Structure of a lectin from Canavalia gladiata seeds: new structural insights for old molecules // BMC Struct. Biol.-2007.-7.-P. 52.

10. Roopashree S., Singh S. A., Gowda L. R., Rao A. G. Dual-function protein in plant defence: seed lectin from Dolichos biflorus (horse gram) exhibits lipoxygenase activity // Biochem J.-2006.395, N 3.-P. 629-639.

11. Osborn T. C., Burow M., Bliss F. A. Purification and characterization of arcelin seed protein from common bean // Plant Physiol.-1988.-86, N 2.-P. 399-405.

12. Peumans W. J., Van Damme E. J. Lectins as plant defence proteins // Plant Physiol.-1995.-109, N 2.-P. 347-352.

13. Herve C., Serres J., Dabos P., Canut H., Barre A., Rouge P., Lescure $B$. Characterization of the Arabidopsis lecRK-a genes: members of a superfamily encoding putative receptors with an extracellular domain homologous to legume lectins // Plant Mol. Biol.-1999.-39, N 4.-P. 671-682.

14. O'Donoghue E. M., Somerweld S. D., Watson L. M., Brummell D. A., Hunter D. A. Galactose metabolism in cell walls of opening and senescing petunia petals // Planta.-2009.-229, N 3.P. 709-721.

15. Brill L. M., Fujshiga N. A., Hackworth C. A., Hirsch A. M. Expression of MsLEC1 transgenes in alfalfa plants causes symbiotic abnormalities // Mol. Plant Microbe Interact.-2004.-17, N 1.-P. 16-26.

16. Van Damme E. J., Lannoo N., Fouquaert E., Peumans W. J. The identification of inducible cytoplasmic/nuclear carbohydratebinding proteins urges to develop novel concepts about the role of plant lectins // Glycoconj. J.-2004.-20, N 7-8.-P. 449-460.

17. Talbot C. F., Etzler M. E. Development and distribution of Dolichos biflorus lectin as measured by radioimmunoassay // Plant Physiol.-1978.-61, N 5.-P. 847-850.

18. Nsimba-Lubaki M., Peumans W. J. Seasonal fluctuations of lectins in barks of elderberry (Sambucus nigra) and black locust (Robinia pseudoacacia)// Plant Physiol.-1986.-80, N 3.- P. 747-751.

19. Oliveira J. T. A., Moraes S. M. D., Cavada B. S., Moreira R. A., Vasconcelos I. M. Protein and lectin mobilization during Erythrina velutina forma aurantiaca seed germination and seedling growth in the dark // Revista Brasil. Fisiol. Vegetal.-1998.-10, N 1.-P. 25-30.

20. Kittur F. S., Lalgondar M., Yu H. Y., Bevan D. R., Esen A. Maize beta-glucosidase-aggregating factor is a polyspecific jacalin-related chimeric lectin, and its lectin domain is responsible for be- 
ta-glucosidase aggregation // J. Biol. Chem.-2007.-282, N 10.P. 7299-7311.

21. Ueda H., Fukushima H., Hatanaka Y., Ogawa H. Solubility insolubility interconversion of sophoragrin, a mannose/glucose-specific lectin in Sophora japonica (Japanese pagoda tree) bark, regulated by the sugar-spesific interaction // Biochem. J.-2004.382, Pt 3.-P. 821-829.

22. Mishkind M., Keegstra K., Palevitz B. Distribution of wheat germ agglutinin in young wheat plants // Plant Physiol.-1980.66, N 5.-P. 950-955.

23. Esteban R., Dopico B., Munoz F. J., Romo S., Labrador E. A seedling specific vegetative lectin gene is related to development in Cicer arietinum // Physiol. Plant.-2002.-114, N 4.-P. 619-626.

24. Bezrukova M. V., Lubyanova A. R., Fatkhutdinova R. A. The involvement of wheat and common bean lectins in the control of cell division in the root apical meristems of various plant species // Russ. J. Plant Physiol.-2011.-58, N 1.-P. 174-180.

25. Wolters H., Jurgens $G$. Survival of the flexible: hormonal growth control and adaptation in plant development // Nat. Rev. Genet.2009.-10, N 5.-P. 305-317.

26. Borrebaeck C. A., Linsefors L. Hormonal regulation of the lectin biosynthesis in callus culture of the Phaseolus vulgaris // Plant Physiol.-1985.-79, N 3.-P. 659-662.

27. Shakirova F. M., Avalbaev A. M., Bezrukova M. V., Gimalov F. $R$. Induction of wheat germ agglutinin synthesis by abscisic and gibberellic acids in roots of wheat seedlings // Plant Growth Reg.-2001.-33, N 2.-P. 111-115.

28. James D. W., Ghosh M., Etzler M. E. Production of a lectin in tissue cultures of Dolichos biflorus // Plant Physiol.-1985.-77, N 3.-P. 630-634.

29. Bezrukova M. V., Aval'baev A. M., Kil'dibekova A. R., Fatkhutdinova R. A., Shakirova F. M. Interaction of wheat lectin with 24epibrassinolide in the regulation of cell division in wheat roots // Dokl. Biol. Sci.-2002.-387, N 1-6.-P. 533-535.

30. Meyer A., Rypniewski W., Szymanski M., Voelter W., Barciszewski J., Betzel C. Structure of mistletoe lectin I from Viscum album in complex with the phytohormone zeatin // Biochim. Biophys. Acta.-2008.-1784, N 11.-P. 1590-1595.

31. Xiang Y., Song M., Wei Z., Tong J., Zhang L., Xiao L., Ma Z., Wang $Y$. A jacalin-related lectin-like gene in wheat is a componenet of the plant defence system // J. Exp. Bot.-2011.-62, N 15.-P. 5471-5483.

32. Zhu-Salzman K., Salzman R. A., Koiwa H., Murdock L. L., Bressan R. A., Hasegawa P. M. Ethylene negatively regulates local expression of plant defense lectin genes // Physiol. Plant.-1998.104, N 3.-P. 365-372.

33. Hoson T., Masuda Y., Sone Y., Misaki A. Xyloglucan antibodies inhibit auxin-induced elongation and cell wall loosening of Azuki bean epicotyls but not of oat coleoptiles // Physiol. Plant.1991.-96, N 2.-P. 551-557.

34. Hoson T., Masuda Y. Effect of lectins on auxin-induced elongation and wall loosening in oat coleoptile and azuki bean epicotyl segments // Physiol. Plant.-1987.-71, N 1.-P. 1-8.

35. Barre A., Herve C., Lescure B., Rouge P. Lectin receptor kinases in plants // Crit. Rev. Plant Sci.-2002.-21, N 4.-P. 379-399.

36. Deng K., Wang Q., Zeng J., Guo X., Zhao X., Tang D., Liu X. A lectin receptor kinase positively regulates ABA response during seed germination and is involved in salt and osmotic stress response // J. Plant Biol.-2009.-52, N 6.-P. 493-500.

37. Xin Z., Wang A., Yang G., Gao P., Zheng Z. L. The Arabidopsis A4 subfamily of lectin receptor kinases negatively regulates abscisic acid response in seed germination // Plant Physiol.-2009.149, N 1.-P. 434-444.
38. Aleksidze G. Ya., Litvinov A. I., Vyskrebentseva E. I. The model of Calvin cycle enzyme organization on thylakoid membranes with the involvement of the photosystem I lectin // Russ. J. Plant Physiol.-2002.-49, N 1.-P. 137-141.

39. Nagano A. J., Fukao Y., Fujiwara M., Hara-Nishimura I. Antagonistic jacalin-related lectins regulate the size of ER body-type beta-glucosidase complexes in Arabidopsis thaliana // Plant Cell Physiol.-2008.-49, N 6.-P. 969-980.

40. Young M. N., Oomen R. P. Analysis of sequence variation among legume lectins. A ring of hypervariable residues forms the perimeter of the carbohydrate-binding site // J. Mol. Biol.-1992.228, N 3.-P. 924-934.

41. Owens R. A., Blackburn M., Ding B. Possible involvement of the phloem lectin in long-distance viroid movement // Mol. Plant Microbe Interact.-2001.-14, N 7.-P. 905-909.

42. Gomez G., Pallas $V$. A long-distance translocatable phloem protein from cucumber forms a ribonucleoprotein complex in vivo with Hop stunt viroid RNA // J. Virol.-2004.-78, N 18.P. 10104-10110.

43. Gomez G., Torres H., Pallas V. Identification of translocatable RNA-binding phloem proteins from melon, potential components of the long-distance RNA transport system // Plant J.-2005.-41, N 1.-P. 107-116.

44. Beneteau J., Renard D., Marche L., Douville E., Lavenant L., Rahbe Y., Dupont D., Vilaine F., Dinant $S$. Binding properties of the N-acetylglucosamine and high-mannose N-glycan PP2-A1 phloem lectin in Arabidopsis // Plant Physiol.-2010.-153, N 3.P. 1345-1361.

45. Matveeva N., Lazareva E., Klyushnik T., Zozulya S., Ermakov I. Lectins of the Nicotiana tabacum pollen grain walls stimulating in vitro pollen germination // Russ. J. Plant Physiol.-2007.-54, N 5.-P. 619-625.

46. Wan J., Patel A., Mathieu M., Kim S. Y., Xu D., Stacey G. A lectin receptor-like kinase is required for pollen development in Arabidopsis // Plant Mol. Biol.-2008.-67, N 5.-P. 469-482.

47. Kovalchuk N. V., Musatenko L. I. Lectins during seed development// Reports Nat. Acad. Sci. Ukraine.-2000.-N 7.-P. 169-173.

48. Komarova E. N. Lectins of stem apices of Rudbeckia and Perilla plants during the transition to flowering under effect of photoperiodical induction // Appl. Biochem. Microbiol.-1998.-34, N 1.-P. 101-105.

49. Priem B., Gross K. C. Mannosyl-and xylosylcontaining glycans promote tomato (Lycopersicon esculentum Mill.) fruit ripening // Plant Physiol.-1992.-98, N 1.-P. 399-401.

50. Yunovitz H., Gross K. C. Delay of tomato fruit ripening by an oligosaccharide N-glican. Interactions with IAA, galactose and lectins // Physiol. Plant.-1994.-90, N 1.-P. 152-156.

51. Chrispeels M. J., Greenwood J. S. Heat stress enhances phytohemagglutinin synthesis but inhibits its transport out of the endoplasmic reticulum // Plant Physiol.-1987.-83, N 4.- P. 778784.

52. Fouquaert E., Peumans W. J., Smith D. F., Proost P., Savvides S. N., Van Damme E. J. The «old» Euonymus europaeus agglutinin represents a novel family of ubiquitous plant proteins // Plant Physiol.-2008.-147, N 3.-P. 1316-1324.

53. Komarova E. N., Vyskrebentseva E. I., Trunova T. I. Activity of lectin-like proteins of the cell walls and the outer organelle membranes as related to endogenous ligands in cold-adapted seedlings of winter wheat // Russ. J. Plant Physiol.-2003.-50, N 4.P. 455-460.

54. Garaeva L. D., Pozdeeva S. A., Timofeeva O. A., Khokhlova L. $P$. Cell-wall lectins during winter wheat cold hardening // Russ. J. Plant Physiol.-2006.-53, N 6.-P. 746-750. 
55. Bezrukova M., Kildibekova A., Shakirova F. WGA reduces the level of oxidative stress in wheat seedlings under salinity // Plant Growth Reg.-2008.-54, N 3.-P. 195-201.

56. Broekaert W. F., van Parijs J., Leyns F., Joos H., Peumans W. J. A chitin-binding lectin from stinging nettle rhizomes with antifungal properties // Science.-1989.-245, N 4922.-P. 1100-1102.

57. Ciopraga J., Gozia O., Tudor R., Brezuica L., Doyle R. J. Fusarium sp. growth inhibition by wheat germ agglutinin // Biochim. Biophys. Acta.-1999.-1428, N 2-3.-P. 424-432.

58. Brambl R., Gade W. Plant seed lectins disrupt growth of germinating fungal spores // Physiol. Plant.-1985.-64, N 3.-P. 402-408.

59. Does M. P., Houterman P. M., Dekker H. L., Cornelissen B. J. $C$. Processing, targeting, and antifungal activity of stinging nettle agglutinin in transgenic tobacco // Plant Physiol.-1999.-120, N 2.-P. 421-431.

60. Rozhnova N. A., Gerashchenkov G. A., Babosha A. V. The effect of arachidonic acid and viral infection on the phytohemagglutinin activity during the development of tobacco acquired resistance // Russ. J. Plant Physiol.-2003.-50, N 5.-P. 661-665.

61. Kanzaki H., Saitoh H., Takahashi Y., Berberich T., Ito A., Kamoun $S$., Terauchi $R$. NbLRK1, a lectin-like receptor kinase protein of Nicotiana benthamiana, interacts with Phytophthora infestans INF1 elicitin and mediates INF1-induced cell death // Planta.-2008.-228, N 6.-P. 977-987.

62. Sprawka I., Golawska S. Effect of the lectin PHA on the feeding behavior of the grain aphid // J. Pest Sci.-2010.-83, N 2.P. 149-155.

63. Osborni T. C., Alexander D. C., Sun S. S., Cardona C., Bliss F. A. Insecticidal activity and lectin homology of arcelin seed protein // Science.-1988.-240, N 4849.-P. 207-210.

64. Moreno J., Altabella T., Chrispeels M. J. Characterization of alpha-amylase-inhibitor, a lectin-like protein in the seeds of Phaseolus vulgaris // Plant Physiol.-1990.-92, N 3.-P. 703-709.

65. Fakhoury A. M., Woloshuk C. P. Inhibition of growth of Aspergillus flavus and fungal alpha-amylases by a lectin-like protein from Lablab purpureus // Mol. Plant Microbe Interact.-2001.14, N 8.-P. 955-961.

66. Sadeghi A., Van Damme E. J., Peumans W. J., Smagghe G. Deterrent activity of plant lectins on cowpea weevil Callosobruchus maculates (F.) oviposition // Phytochemistry.-2006.-67, N 18.-P. 2078-2084.

67. Wang W., Hause B., Peumans W. J., Smagghe G., Mackie A., Fraser R., van Damme E. J. The Tn antigen-specific lectin from gound ivy is an insecticidal protein with an unusual physiology // Plant Physiol.-2003.-132, N 3.-P. 1322-1334.

68. Citores L., Ferreras J. M., Iglesias R., Carbajales M. L., Arias F. J., Jimenez P., Rojo M. A., Girbes T. Molecular mechanism of inhibition of mammalian protein synthesis by some four chain agglutinins. Proposal of an extended classification of plant ribosome inactivating proteins (rRNA N-glycosidases) // FEBS Lett.-1993.-329, N 1-2.-P. 59-62.

69. Subramanyam S., Smith D. F., Clemens J. C., Webb M. A., Sardesai N., Williams C. E. Functional characterization of HFR1, a high-mannose N-glycan-specific wheat lectin induced by Hessian fly larvae // Plant Physiol.-2008.-147, N 3.-P. 1412-1426.

70. Fountain D. W., Foard D. E., Replogle W. D., Yang W. K. Lectin release by soybean seeds // Science.-1977.-197, N 4309.P. 1185-1187.

71. Kjemtrup S., Borkhsenious O., Raikhel N. V., Chrispeels M. J. Targeting and release of phytohemagglutinin from the roots of bean seedlings // Plant Physiol.-1995.-109, N 2.-P. 603-610.
72. Dazzo F. B., Truchet $G$. L. Interactions of lectins and their saccharide receptors in the Rhizobium-legume symbiosis // J. Membr. Biol.-1983.-73, N 1.-P. 1-16.

73. van Rhijn P., Fujishige N. A., Lim P. O., Hirsch A. M. Sugarbinding activity of pea lectin enhances heterologous infection of transgenic alfalfa plants by Rhizobium leguminosarum biovar viciae // Plant Physiol.-2001.-126, N 1.-P. 133-144.

74. Baimiev A. Kh., Gubaidullin I. I., Chemeris A. V., Vakhitov V. A. Contribution of lectin sugar-binding peptides structure determines specificity of rhizobium-legume symbiosis in Galega orientalis and Galega officinalis // Mol. Biol. (Mosk).-2005.-39, N 1.P. 103-111.

75. Diaz C. L., Spaink H. P., Kijne J. W. Heterologous rhizobial lipochitin oligosaccharides and chitin oligomers induce cortical cell divisions in red clover roots, transformed with the pea lectin gene // Mol. Plant Microbe Interact.-2000.-13, N3.-P. 268-276.

76. Etzler M. E., Kalsi G., Ewing N. N., Roberts N. J., Day B. R., Murphy J. B. A nod factor binding lectin with apyrase activity from legume roots // Proc. Natl Acad. Sci. USA.-1999.-96, N 10.-P. 5856-5861.

77. Govindarajulu M., Kim S. Y., Libault M., Berg R. H., Tanaka K., Stacey G., Taylor C. G. GS52 ecto-apyrase plays a critical role during soybean nodulation // Plant Physiol.-2009.-149, N 2.P. 994-1004.

78. Navarro-Gochicoa M. T., Camut S., Timmers A. C., Niebel A., Herve C., Boutet E., Bono J. J., Imberty A., Cullimore J. V. Characterization of four lectin-like receptor kinases expressed in roots of Medicago truncatula. Structure, location, regulation of expression, and potential role in the symbiosis with Sinorhizobium meliloti // Plant Physiol.-2003.-133, N 4.-P. 1893 1910.

79. Kardailsky I. V., Sherrier D. J., Brewin N. J. Identification of a new pea gene, $P$ sNlecl, encoding a lectin-like glycoprotein isolated from the symbiosomes of root nodules // Plant Physiol.1996.-111, N 1.-P. 49-60.

80. Sherrier D. J., Borisov A. Y., Tikhonovich I. A., Brewin N. J. Immunocytological evidence for abnormal symbiosome development in nodules of the pea mutant line Sprint2Fix ${ }^{-}(\operatorname{sym} 31) / /$ Protoplasma.-1997.-199, N 1-2.-P. 57-68.

81. Bolanos L., Redondo-Nieto M., Rivilla R., Brewin N. J., Bonilla I. Cell surface interactions of Rhizobium bacteroids and other bacterial strains with symbiosomal and peribacteroid membrane components from pea nodules // Mol. Plant Microbe Interact.2004.-17, N 2.-P. 216-223.

82. van Rhijn P., Goldberg R. B., Hirsch A. M. Lotus corniculatus nodulation specificity is changed by the presence of a soybean lectin gene // Plant Cell.-1998.-10, N 8.-P. 1233-1250.

83. Sreevidya V., Hernandez-Oane R., So R., Sullia S., Stacey G., Ladha J., Reddy P. Expression of the legume symbiotic lectin genes and promotes rhizobial colonization of roots in rice // Plant Sci.-2005.-169, N 4.-P. 726-736.

84. D'Haeze W., Holsters M. Nod factor structures, responses, and perception during initiation of nodule development // Glycobiology.-2002.-12, N 6.-P. 79R-105R.

85. Kosenko L. V., Mandrovskaya N. M. Influence of pea lectin on growth of pea microsymbiont and exoglycans biosynthesis // Microbiology (Russia).-1998.-67, N 5.-P. 626-630.

86. Lodeiro A. R., Lopez-Garcia S. L., Vazquez T.E., Favelukes G. Stimulation of adhesiveness, infectivity, and competitiveness for nodulation of Bradyrhizobium japonicum by its pretreatment with soybean seed lectin // FEMS Microbiol. Lett.-2000.-188, N 2.-P. 177-184. 
87. Perez-Gimenez J., Mongiardini E. J., Althabegoiti M. J., Quelas J. I., Lopez-Garcia S. L., Lodeiro A. R. Soybean lectin enhances biofilm formation by Bradyrhizobium japonicum in the absence of plants // Int. J. Microbiol.-2009.-2009.-ID 719367, 8 p.

88. Martinez C. R., Albertini A. V. P., Figueirdo M. V. B., Silva V. L., Sampaio A. H., Cavada B. S., Lima-Filho J. L. Respiratory stimulus in Rhizobium sp. by legume lectins // World J. Microbiol. Biotechnol.-2004.-20, N 1.-P. 77-83.

89. Melnykova N. M., Kovalchuk N. V., Kots S. Ya., Musatenko L. I. Influence of soybean seeds lectins on the legume-rhizobium symbiosis formation and functioning // Fiziol. Biokhim. Cult. Plants.-2009.-41, N 5.-P. 439-446.

90. Halverson L. J., Stacey G. Effect of lectin on nodulation by wild-type Bradyrhizobium japonicum and a nodulation-defective mutant// Appl. Environ. Microbiol.-1986.-51, N 4.-P. 753-760.

91. Ridge R. W., Rolfe B. G. Lectin binding to the root and root hair tips of the tropical legume Macroptilium atropurpureum Urb. // Appl. Environ. Microbiol.-1986.-51, N 2.-P. 328-332.

92. Frenzel A., Manthey K., Perlick A. M., Meyer F., Puhler A., Kuster $H$., Krajinski $F$. Combined transcriptome profiling reveals a novel family of arbuscular mycorrhizal-specific Medicago truncatula lectin genes // Mol. Plant Microbe Interact.-2005.-18, N 8.-P. 771-782.

93. Karpati E., Kiss P., Ponyi T., Fendrik I., de Zamaroczy M., Orosz $L$. Interaction of Azospirillum lipoferum with wheat germ agglutinin stimulates nitrogen fixation // J. Bacteriol.-1999.-181, N 13.-P. 3949-3955.

94. Antonyuk L. P., Ignatov $V$. V. The role of wheat germ agglutinin in plant-bacteria interactions: a hypothesis and the evidence in its support // Russ. J. Plant Physiol.-2001.-48, N 3.-P. 364-369.

95. Karpova I. S., Koretskaya N. V. Study on modifying action of lectins on the toxic and mutagenic effects of $\mathrm{Ni}$ (II) ions in Bacillus subtilis culture // Biopolym. Cell.-2003.-19, N 3.P. 224-230.

96. Rudiger H., Gabius H. J. Plant lectins: occurrence, biochemistry, functions and applications // Glycoconj. J.-2001.-18, N 8.P. 589-613.
97. Qureshi I. A., Dash P. K., Srivastava P. S., Koundal K. R. Isolation and characterization of a lectin gene from seeds of chickpea (Cicer arietinum L.) // DNA Seq.-2007.-18, N 3.-P. 196-202.

98. Chen Y., Peumans W. J., Hause B., Bras J., Kumar M., Proost P., Barre A., Rouge P., van Damme E. J. Jasmonate methyl ester induces the synthesis of a cytoplasmic/nuclear chitooligosaccharide-binding lectin in tobacco leaves // FASEB J.-2002.-16, N 8.P. 905-907.

99. Grunwald I., Heinig I., Thole H. H., Neumann D., Kahmann U., Kloppstech K., Gau A. E. Purification and characterization of a jacalin-related, coleoptile specific lectin from Hordeum vulgare // Planta.-2007.-226, N 1.-P. 225-234.

100. Jiang J. F., Han Y., Xing L. J., Xu Y. Y., Xu Z. H., Chong K. Cloning and expression of a novel cDNA encoding a mannose-specific jacalin-related lectin from Oryza sativa // Toxicon.-2006.47, N 1.-P. 133-139.

101. Baimiev Al. Kh., Gubaidullin I. I., Baimiev An. Kh., Chemeris A. $V$. The effects of natural and hybrid lectins on the legume-rhizobium interactions // Appl. Biochem. Microbiol.-2009.-45, N 1.P. 74-80.

102. Nagadhara D., Ramesh S., Pasalu I. C., Rao Y. K., Sarma N. P., Reddy V. D., Rao K. V. Transgenic rice plants expressing the snowdrop lectin gene ( $g n a$ ) exhibit high-level resistance to the whitebacked planthoper (Sogatella furcifera) // Theor. Appl. Genet.-2004.-109, N 7.-P. 1399-1405.

103. Lin P., Ye X., $\mathrm{Ng} T$. Purification of melibiose-binding lectins from two cultivars of chinese black soybeans // Acta Biochim Biophys. Sin (Shanghai).-2008.-40, N 12.-P. 1029-1038.

104. Krugova O. D., Mandrovs'ka N. M., Kyrychenko O. V. Effect of exogenous lectin on the endogenous lectin activity and the activity of antioxidant enzymes and flavonoid content in wheat // Ukr. Biokhim. Zh.-2006.-78, N 2.-P. 106-112.

Received 22.01.12 